\title{
$\mathrm{Al}-\mathrm{Mg}$ 合金板の降伏応力異方性に及ぼす 集合組織と転位セル壁配列の影響
}

\author{
佐久間尚幸* ·小松原俊雄* · 小松 伸也**
}

Journal of Japan Institute of Light Metals, Vol. 52, No. 2(2002), pp. 53-57

\section{Effects of texture and arrangements of dislocation cell walls on yield stress anisotropy in $\mathrm{Al}-\mathrm{Mg}$ alloy sheets}

Takayuki SAKUMA*, Toshio KOMATSUBARA* and Shin-ya KOMATSU**

\begin{abstract}
Yield stress anisotropy in $85 \%$ cold rolled and low temperature annealed sheets of $\mathrm{Al}-\mathrm{Mg}$ alloys was studied from viewpoints of both texture and microstructure using X-ray diffraction, resistivity measurement and TEM. Texture analysis by X-ray diffraction suggests that the texture has little effect on the yield stress anisotropy of cold rolled and annealed sheets. In contrast, the result of resistivity suggests that the anisotropic arrangements of dislocation cell walls have a significant effect on the yield stress anisotropy. TEM observation shows that deformation zones developed around coarse particles have a random arrangement to the rolling direction and shear bands have geometrical arrangement to it. Further, they have considerably high dislocation density. It is concluded that these dense dislocation regions, which act as obstacles to slip, influence the yield stress anisotropy of cold rolled and annealed sheets.

(Received June 4, 2001)
\end{abstract}

Keywords: Al-Mg alloys, yield stress anisotropy, deformation zones, shear bands

\section{1. 緒言}

圧延材には耳率，r 值，機械的性質などが圧延方向との角 度で変わる面内異方性があり，材料特性に様々な影響を及ぼ す。そのため，それぞれの用途に応じて異方性の最適化が図 られている1)。

一般には，異方性と集合組織は密接な関係がある22) と考光 られている。しかし, 過去には高密度転位壁やマイクロバン ドの幾何学的配列をモデル化して，アルミニウム冷間圧延板 の降伏応力異方性を検討した例 ${ }^{3)}$ もある。したがって, 集合 組織だけでは異方性のすべてを説明できず，転位セル壁など の配列異方性も考慮して, 降伏応力の異方性を検討する必要 がある。

本研究では, 転位セル壁の配列を大きく変えた $\mathrm{Al}-\mathrm{Mg}$ 合 金を用いて，冷間圧延板の焼なましによる降伏応力異方性の 変化を集合組織とミクロ組織の観点から検討した。

\section{2. 実験方法}

\section{1 試料と加工熱処理}

試料は，飲料用缶蓋材に使用される5182合金とそれと同じ $\mathrm{Mg}$ 濃度を有する高純度 $\mathrm{Al}-4.6 \% \mathrm{Mg}$ 合金である。試料の化 学成分を Table 1 亿示す。工場規模で製造した熱間圧延板を 厚さ $2.0 \mathrm{~mm}$ まで冷間圧延した後，中間焼なましを施した。
Table 1 Chemical composition (mass\%) of specimens

\begin{tabular}{c|c|c|c|c|c}
\hline \hline & $\mathrm{Mg}$ & $\mathrm{Si}$ & $\mathrm{Fe}$ & $\mathrm{Mn}$ & $\mathrm{Al}$ \\
\hline 5182 & 4.63 & 0.11 & 0.23 & 0.34 & $\mathrm{bal}$. \\
$\mathrm{Al}-4.6 \mathrm{Mg}$ & 4.63 & 0.005 & 0.002 & - & bal. \\
\hline
\end{tabular}

幅 $200 \mathrm{~mm} ，$ 長さ $200 \mathrm{~mm}$ に切断した板材の中間焼なましで は，結晶粒サイズを変えるために 5182 合金は $550^{\circ} \mathrm{C}, \mathrm{Al}-4.6$ $\% \mathrm{Mg}$ 合金は $400^{\circ} \mathrm{C}$ 抢よび $550^{\circ} \mathrm{C}$ で $1 \mathrm{~min}$ 塩浴中で熱処理し た。以下，それぞれ $5182-550^{\circ} \mathrm{C}, 4.6 \mathrm{Mg}-400^{\circ} \mathrm{C}, 4.6 \mathrm{Mg}-550$ ${ }^{\circ} \mathrm{C}$ と略記する。その後, 厚さ $0.3 \mathrm{~mm}$ まで $85 \%$ 冷間圧延し, バッチ炉中にて $120,160,200,240^{\circ} \mathrm{G} て ゙ 1 \mathrm{~h}$ の最終焼なましを 施した。

\section{2 各種測定と組織観察}

引張試験, 比抵抗測定用試料は冷間圧延板と最終焼なまし 板から, 圧延方向に対して $0,45,90^{\circ}$ 方向に切出した。引張 試験はJIS5 号試験片を用い, クロスヘッド速度 $5 \mathrm{~mm} / \mathrm{min}$ で室温にて繰返し数 3 で試験した。

X 線集合組織は板厚中央部で測定し， $\{200\},\{220\},\{111\}$ の不完全極点図から結晶方位分布関数（ODF）を計算した。 組織観察には, 偏光顕微鏡, 微分干渉顕微鏡, TEM を使用 した。

\footnotetext{
* スカイアルミニウム秼技術研究所（干366-8511 埼玉県深谷市上野台1351）。Technical Research Center, SKY Aluminium Co., Ltd. (1351, Uwanodai, Fukaya-shi, Saitama 366-8511).

** 関西大学工学部 (吹田市)。Faculty of Engineering, Kansai University (Suita-shi, Osaka).
} 


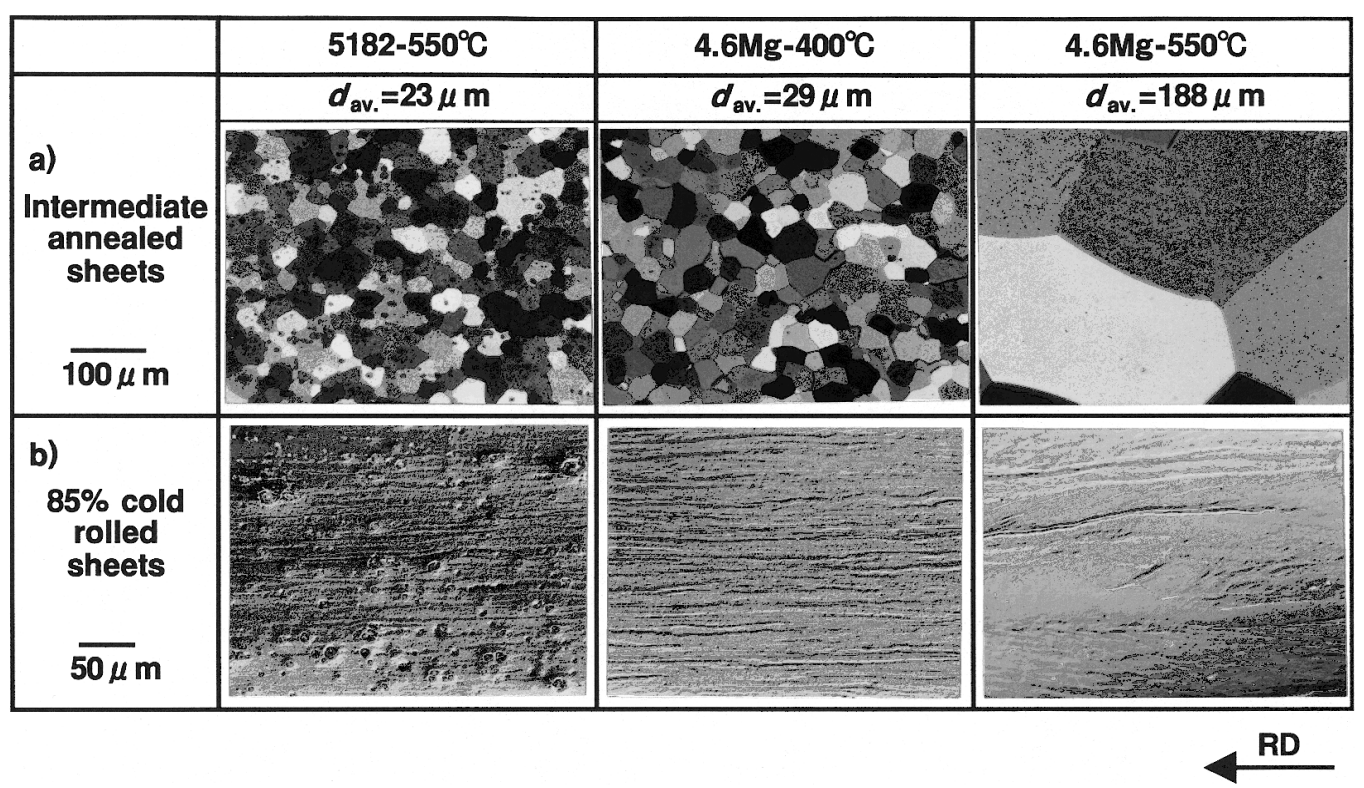

Fig. 1 Optical micrographs of intermediate annealed and 85\% cold rolled sheets. a) Grain size, b) Distribution of coarse particles and macroscopic shear bands. (longitudinal sections)

Table 2 Constants of Matthiessen empirical relation (MER) and correlation factor $(r)$

\begin{tabular}{c|c|c|c}
\hline \hline Specimen & $\alpha$ & $\beta$ & $r$ \\
\hline $5182-5500^{\circ} \mathrm{C}$ & 21.72 & 5.302 & 0.9867 \\
$4.6 \mathrm{Mg}-400^{\circ} \mathrm{C}$ & 22.75 & 3.368 & 0.9895 \\
$4.6 \mathrm{Mg}-550^{\circ} \mathrm{C}$ & 23.13 & 2.982 & 0.9911 \\
\hline
\end{tabular}

\section{3 比抵抗の測定法とマティーセン則経験式の決定}

$0.3^{\mathrm{t}} \times 3.0^{\mathrm{w}} \times 180^{\mathrm{l}} \mathrm{mm}$ 飞せん断した試料の $77 \mathrm{~K}$ と $300 \mathrm{~K} て ゙$ の密度質量法サイズファクタによる比抵抗 $\left(\rho_{\mathrm{D} 77}\right.$ と $\left.\rho_{\mathrm{D} 300}\right)$ を, $\mathrm{Al}-\mathrm{Mg}$ 合金飞適用された方法4)で測定した。抵抗比 $(R$ $\left.=\rho_{\mathrm{D} 300} / \rho_{\mathrm{D} 77}\right)$ と比抵抗 $\left(\rho_{77}\right)$ の関係で表すマティーセン則 経験式 $(\mathrm{MER})^{4) * 1}$ *用いて寸法測定誤差を平均化した。本 論文で示す $77 \mathrm{~K}$ での比抵抗 $\rho_{\mathrm{M} 77}$ の添字 M は MER による ことを意味する。

各試料ごとの MER は, 先に述べた最終暁なまし条件で個 別に熱処理した試料と冷間圧延状態から累積等時熱処理した 試料の測定值を用いて決定した。MERを $\rho_{77}(\mathrm{n} \Omega \mathrm{m})=$ $\alpha /(R-1)+\beta$ で示した場合の定数 $\alpha, \beta$ と相関係数 $r$ を Table 2 亿示す。

\section{3. 実験結果と考察}

\section{1 中間焼なまし板と冷間圧延板の $\mathrm{OM}$ 組織}

Fig. 1 飞は中間焼なまし板と $85 \%$ 冷間圧延板の長さ方向断 面での光学顕微鏡組織写真を示し，Table 3 亿 Fig. 1 で示し た各試料の組織の特徵を要約した。 $5182-550^{\circ} \mathrm{C}$ は不純物 $\mathrm{Fe}$, $\mathrm{Si}$ や添加元素 $\mathrm{Mn}$ を含を粗大晶出物が最大径 $1 \mu \mathrm{m}$ 以上の粒 子として冷間圧延板中に $2.17 \times 10^{3}$ 個 $/ \mathrm{mm}^{2}$ 存在して拈り，

\footnotetext{
*1 マティーセン則から $\rho_{77}=\left(\rho_{300}^{\text {pure }}-\rho_{77}^{\text {pure }}\right) /(R-1)$ が誘導できる が，マティーセン則からのずれ $\mathrm{DMR}^{13)}$ や測定誤差が影響する ので， $\rho_{77}$ と $1 /(R-1)$ の実測值のプロットを直線回帰して勾配 $\alpha$ と切片 $\beta$ を求めたものをマティーセン則経験式と呼んでいる。
}

Table 3 Characteristics of several specimens

\begin{tabular}{c|c|c|c}
\hline \hline \multirow{2}{*}{$\begin{array}{c}\text { Thermomechanical } \\
\text { treatments }\end{array}$} & \multicolumn{2}{|c}{ Intermediate annealing } \\
\cline { 2 - 4 } & & \multicolumn{2}{|c}{$85 \%$ cold rolling } \\
\hline Characteristics & $\begin{array}{c}\text { Grain } \\
\text { size }\end{array}$ & $\begin{array}{c}\text { Coarse } \\
\text { particle }\end{array}$ & $\begin{array}{c}\text { Shear } \\
\text { band }\end{array}$ \\
\hline $5182-550^{\circ} \mathrm{C}$ & fine & many & few \\
$4.6 \mathrm{Mg}-400^{\circ} \mathrm{C}$ & fine & trace & few \\
$4.6 \mathrm{Mg}-550^{\circ} \mathrm{C}$ & coarse & trace & many \\
\hline
\end{tabular}

$\mathrm{Al}-\mathrm{Fe}-(\mathrm{Mn})-(\mathrm{Si})$ 以外に $\mathrm{Mg}_{2} \mathrm{Si}$ が認められた。 $5182-550^{\circ} \mathrm{C}$ は冷間圧延前の粒径が20～30 $\mu \mathrm{m}$ になるように中間焼なまし を施しているため, 冷間圧延後には旧結晶粒を貫通するマク ロなせん断帯は，発達していなかった。

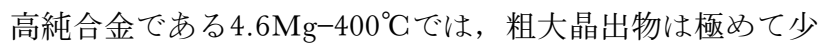
なく, 冷間圧延板での数密度は 80 個 $/ \mathrm{mm}^{2}$ であった。中間焼 なまし時の再結晶粒径は5182-550 $\mathrm{C}$ と同等であるため, せん 断帯は5182-550ㄷほ核同様にあまり発達していなかった。

$4.6 \mathrm{Mg}-550^{\circ} \mathrm{C}$ では, 中間焼なまし時の再結晶粒を $200 \mu \mathrm{m}$ 程度の粗大粒に成長させたため, 冷間圧延後には旧結晶粒を 貫通するマクロなせん断帯が著しく発達した5)。

\section{2 最終焼なましによる降伏応力と異方性の変化}

Fig. 2 に各試料の $85 \%$ 冷間圧延板の最終焼なましによる 0 , 45, $90^{\circ}$ 方向の降伏応力と異方性 ( $\Delta Y S: 0,45,90^{\circ}$ 方向で の最大降伏応力と最小降伏応力の差）の変化を示す。冷間圧 延ままの降伏応力は，いずれの試料も $45^{\circ}$ 方向が最も低く, $0^{\circ}$ 方向が最も高い。しかし, 降伏応力の異方性の程度は試料

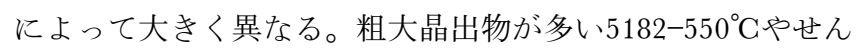
断帯が発達した $4.6 \mathrm{Mg}-550^{\circ} \mathrm{C}$ の場合には, $45^{\circ}$ 方向の降伏応 力が $0,90^{\circ}$ 方向に比べて特に低くなり， $\triangle Y S$ はそれぞれ 39 , $28 \mathrm{MPa}$ と大きな值を示した。しかし， $4.6 \mathrm{Mg}-400^{\circ} \mathrm{C} の \Delta Y S$ は $6 \mathrm{MPa}$ と小さかった。

冷間圧延板を焼なました場合， $5182-550^{\circ} \mathrm{C}$ と $4.6 \mathrm{Mg}-550^{\circ} \mathrm{C}$ 

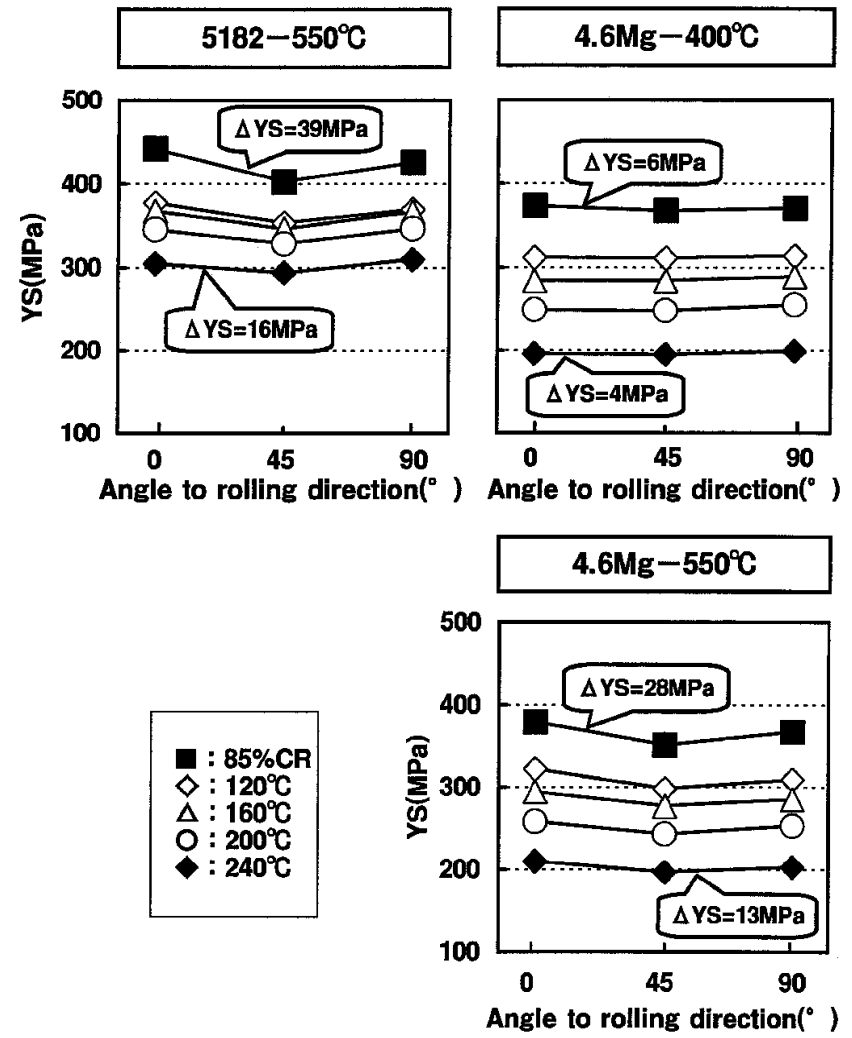

Fig. 2 Angular variation in yield stress of $85 \%$ cold rolled and annealed sheets. Yield stress anisotropy, expressed as $\Delta Y S\left(\Delta Y S=Y S_{\max .}-Y S_{\min }\right)$, is also shown in the figures.

は焼なましによる降伏応力の低下に伴い $\Delta Y S$ が大きく減少 した。 $240^{\circ} \mathrm{C}$ 焼なまし後の $\Delta Y S$ はそれぞれ $16 ， 13 \mathrm{MPa}$ であ った。しかし，冷間圧延ままの異方性が小さい $4.6 \mathrm{Mg}-400^{\circ} \mathrm{C}$ の場合には，焼なましによる $\Delta Y S$ の変化も小さく，240 ${ }^{\circ} \mathrm{C}$ 焼 なまし後の $\Delta Y S$ は $4 \mathrm{MPa}$ であった。

\section{3 最終焼なましによる降伏応力異方性と集合組織の} 変化

Fig. 3 亿各試料の $85 \%$ 冷間圧延状態と $240^{\circ} \mathrm{C}$ 最終焼なまし 状態の $\psi_{2}=45^{\circ}$ 断面での ODF を示す。 $5182-550^{\circ} \mathrm{C}$ は $\mathrm{Cu}$ 方 位と Brass 方位 $(\mathrm{Br})$ から構成される圧延集合組織であった。

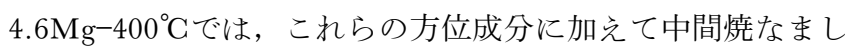
時に発達したCube 方位の残存もわずかに認められた。 $4.6 \mathrm{Mg}-550^{\circ} \mathrm{C}$ の場合は $5182-550^{\circ} \mathrm{C}$ と同様の方位成分であった が， $\mathrm{Cu}$ 方位が特に発達しており, 明らかに他の 2 試料とは 異なる集合組織を示した。しかし，いずれの試料でも， $240^{\circ} \mathrm{C}$ までの焼なましにより集合組織はほとんど変化しなかった。 なお， $\psi_{2}=65^{\circ}$ 断面で現れる $\mathrm{S}$ 方位も，焼なましによる変化 は認められなかった。

$5182-550^{\circ} \mathrm{C}$ と $4.6 \mathrm{Mg}-550^{\circ} \mathrm{C}$ 集合組織は大きく異なるが， Fig. 2 亿示したよらに，最終焼なましによる降伏応力異方性 の変化は同一の傾向であった。また， $5182-550^{\circ} \mathrm{C}$ と $4.6 \mathrm{Mg}$ $400^{\circ} \mathrm{C}$ の集合組織は，後者に存在する中間焼なまし時の Cube 方位を除き，圧延集合組織は比較的よく似ていた。し かし，両者の最終焼なましによる $\Delta Y S$ の挙動は大きく異な っていた。

\section{4 最終焼なましによる軟化異方性と比抵抗の関係}

小松ら ${ }^{6), 7)}$ は $\mathrm{Al}-\mathrm{Mg}$ 合金で，冷間圧延によって導入される
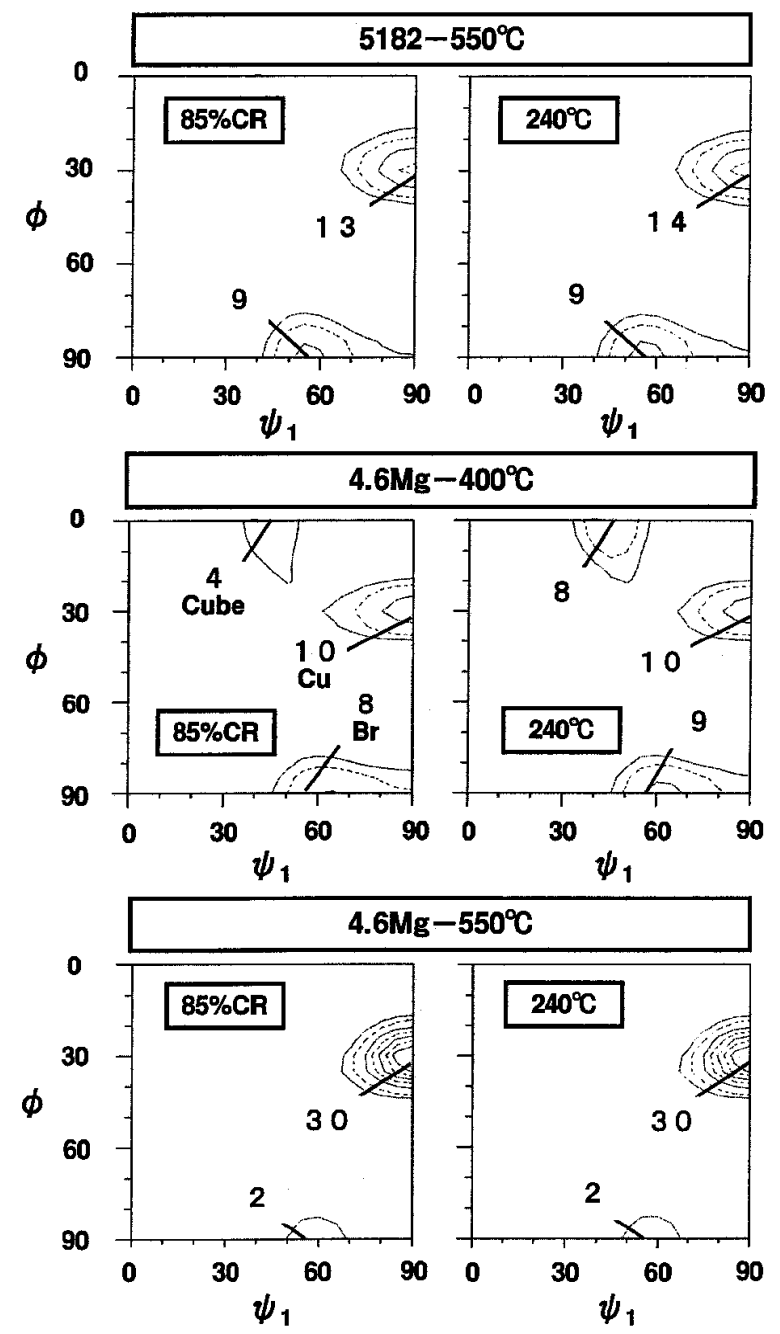

Fig. 3 Orientation distribution functions of $\psi_{2}=45^{\circ}$ section of $85 \%$ cold rolled and $240^{\circ} \mathrm{C}$ annealed sheets.

格子欠陥, 主として転位の密度増加に対応する降伏応力と比 抵抗の増加には, 上い相関があることを報告している。そこ で, 最終焼なまし時の軟化異方性についても比抵抗を用いて 検討した。

Fig. 4a）に $4.6 \mathrm{Mg}-400^{\circ} \mathrm{C} の 85 \%$ 冷間圧延後の最終焼なまし に上る $0,45,90^{\circ}$ 方向の軟化量を, b) 飞比抵抗減少量を示 す。焼なましによる軟化量には異方性が認められ， $0^{\circ}$ 方向が 最も大きく, $45,90^{\circ}$ 方向の順汇小さくなる。この軟化量の 異方性と対応して, 比抵抗減少量にも異方性が認められた。

比抵抗減少量の異方性は, (1)転位七儿壁配列の異方性, (2) Hashimoto ${ }^{8)}$ らが報告した $4.2 \mathrm{~K}$ での比抵抗に及ぼす結晶方位 依存性, (3) $\beta \mathrm{Al}-\mathrm{Mg}$ 系析出物分布密度の異方性などの因子 に支配されることが考光られる。そこで, 比抵抗の異方性に 影響する因子について検討した。

Fig. 5 亿 $4.6 \mathrm{Mg}-550^{\circ} \mathrm{C}$ の $85 \%$ 冷間圧延板の最終焼なましに よる $0,45,90^{\circ}$ 方向の比抵抗の変化を示寸。この試料は,

Fig. 3 から明らかなよら飞結晶方位の分布密度異方性が強 く, 更に最終焼なましを施しても集合組織はまったく変化し ない。仮に，方位異方性が比抵抗流響するとすれば，冷間 圧延ままの比抵抗の異方性は, 焼なました後でも変わらない はずである。しかし，冷間圧延板で最も高い比抵抗を示した 0方向は, 焼なましによって最も低い比抵抗の方向へと変化 

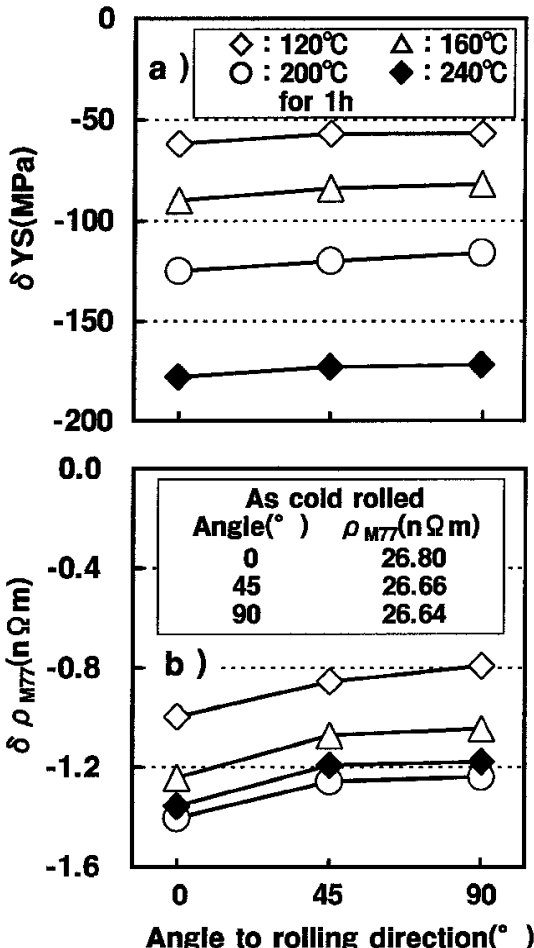

Fig. 4 Decrement from $85 \%$ cold rolled state in a) yield stress $(\delta \mathrm{YS})$ and b) resistivity $\left(\delta \rho_{\mathrm{M} 77}\right)$ by annealing for $1 \mathrm{~h}$. Specimen; $4.6 \mathrm{Mg}-400^{\circ} \mathrm{C}$

して扣り，これは集合組織が比抵抗の異方性に影響していな いことを示唆している。

次に，析出物分布密度の異方性について検討した。 Fig. 4b)で示した最終焼なましによる各方向の比抵抗減少量 が $240^{\circ} \mathrm{C}$ よも $200^{\circ} \mathrm{C}$ での焼なましの方が大きな原因は，

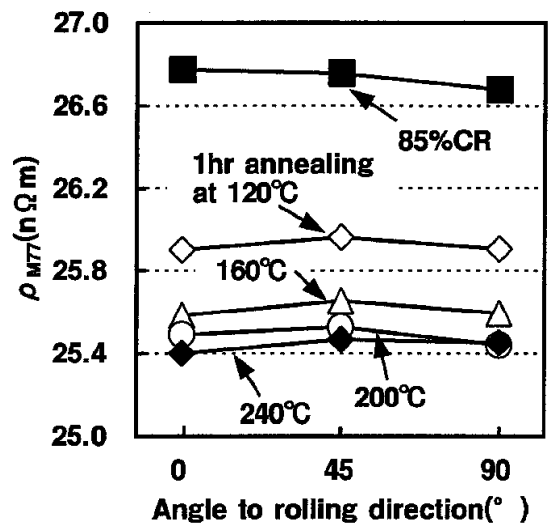

Fig. 5 Angular variation in resistivity of cold rolled and annealed sheets. Specimen; $4.6 \mathrm{Mg}-550^{\circ} \mathrm{C}$

$\mathrm{Al}_{3} \mathrm{Mg}_{2}$ (もしくは $\mathrm{Al}_{8} \mathrm{Mg}_{5}$ ) に近い組成の $\beta^{\prime}$ 等9)の遷移析出 相 (以後, 析出相と略記する) の出現と消滅が影響7)してお り, 析出相の影響は無視できない。しかし, 析出相は冷間圧 延によって形成された転位セル壁上に出現し，その配列の異 方性と密接な関係がある ${ }^{10)}$ ため, 比抵抗への影響は転位セル 壁によるものと重複する可能性がある。

以上のことから, 比抵抗の異方性には, 冷間圧延によって 形成された転位セ儿壁配列の異方性の影響が大きいと考えら れる。更に, Fig. 4a）とb)で軟化量と比抵抗減少量が類似の 挙動を示したことから，焼なまし板で現れる軟化の異方性に も, 析出物と転位セ儿壁配列の異方性が影響している可能性 がある。

\section{5 冷間圧延板の TEM 組織}

Fig. 6 に85\%冷間圧延した $5182-550^{\circ} \mathrm{C} の$ TEM 組織を示す。 $\mathrm{Al}-\mathrm{Fe}-\mathrm{Mn}$ 系の晶出物（図中(3)）周辺に形成された Defor-

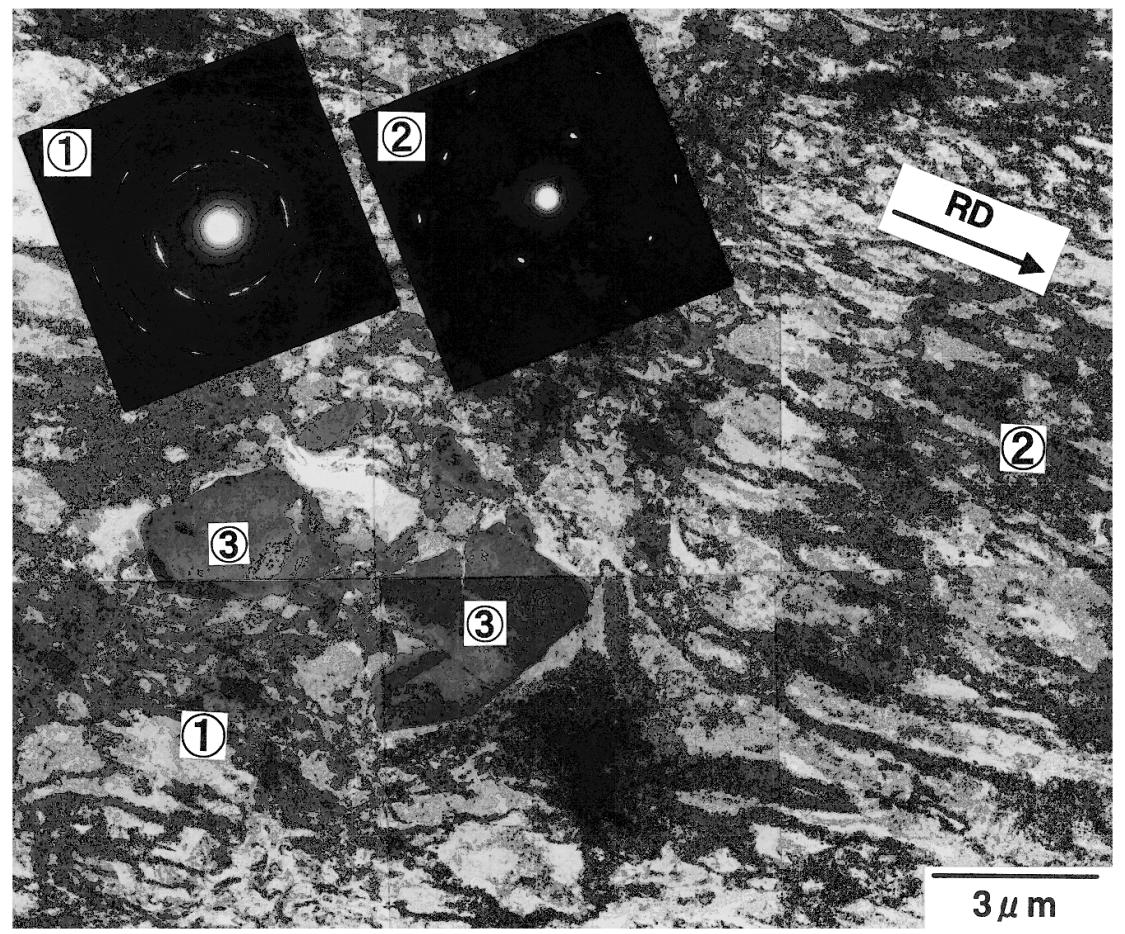

Fig. 6 TEM microstructure of $85 \%$ cold rolled $5182-550^{\circ} \mathrm{C}$ specimen showing dislocation cell walls developed around coarse particles. (1) deformation zone, (2) dislocation cell walls paralleled to the rolling direction, (3) coarse particles. 


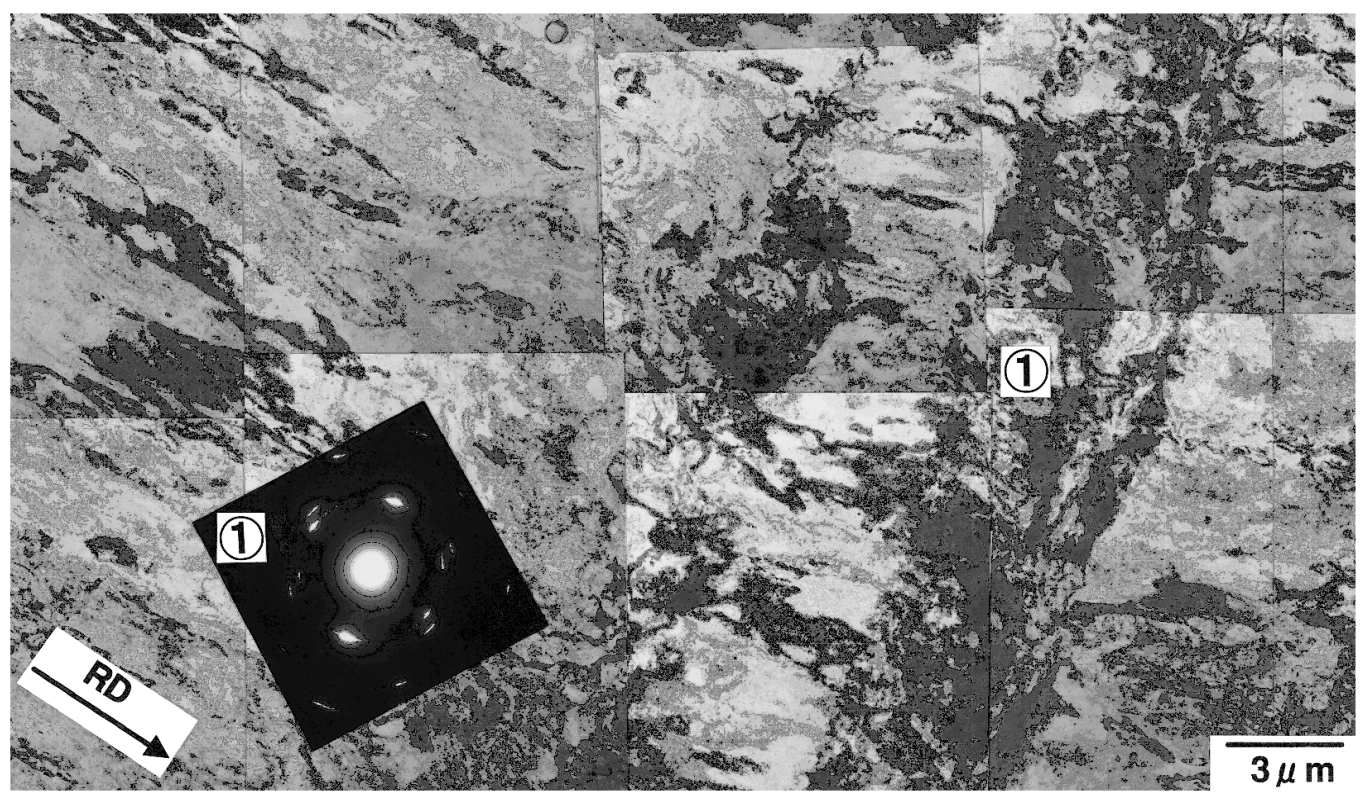

Fig. 7 TEM microstructure of $85 \%$ cold rolled $4.6 \mathrm{Mg}-550^{\circ} \mathrm{C}$ specimen showing (1) shear band intersecting dislocation cell walls paralleled to the rolling direction.

mation Zone ${ }^{11)}$ 中の転位セル（11)の領域）と圧延方向に伸長 した転位セル(2)の領域)を制限視野回折像と合せて示した。 Deformation Zone は, 晶出物から数 $\mu \mathrm{m}$ 程度離れた領域まで 発達して扣り，圧延方向（RD）に対して無秩序な配列であ った。また，その領域内の転位セルサイズは，(2)の領域の転 位セルサイズよりも非常に小さく，高転位密度の領域である ことを示している。

Fig. 7 には， $85 \%$ 冷間圧延した $4.6 \mathrm{Mg}-550{ }^{\circ} \mathrm{C}$ の TEM 組織 を示した。せん断帯の配列は，幾何学的であることが知られ て扣り ${ }^{12)}$ ，Fig. 7 のらな板表面からの観察の場合には, RD に対して直角方向に現れる。また，Fig. 6 で示した Deformation Zone と同様に, せん断帯内部の転位セルサイ ズは非常に小さい。

Deformation Zone やせ九断帯の内部では，圧延方向に伸 長した転位セルは観察されない。更に，七ル壁は厚く転位は 密集して扣り，非常に高密度な転位線を含む領域であること を示している。したがって，圧延方向に伸長した転位セルの すべり変形挙動とは異なることが予想される。また，引張方 向によっては, すべり変形の起こりやすさに差が生じる可能 性も考えられる。そのため, 冷間圧延状態で Deformation Zone やせん断帯が顕著な場合には, 冷間圧延板の降伏応力 の異方性は大きくなる。しかし，冷間圧延板を焼なました場 合には, このような高密度の転位領域から優先的に回復が生 じる。したがって, 引張試験時のすべり変形への妨害が弱ま り，降伏応力の異方性は低下寸ると考兄られる。

\section{4. 結言}

粗大晶出物量とせん断帯の発達レベルを大きく変えた $\mathrm{Al}-$ $\mathrm{Mg}$ 合金を用い，集合組織とミクロ組織の観点から冷間圧延 板の焼なましによる降伏応力異方性の变化について検討し， 以下の結論を得た。

(1) 冷間圧延によって Deformation Zone やせん断帯が材 料内部に発達した場合には, 降伏応力異方性は大きくなる。 また，この異方性には集合組織との対応は皃とんど認められ
ない。

（2）冷間圧延板を焼なました場合には，圧延方向との角度 に依存して軟化量の異方性が現れ, その結果, Deformation Zone やせん断帯が顕著な試料では, 降伏応力の異方性は低 減する。

（3）焼なまし時に現れる軟化量と比抵抗減少量の異方性に は, よい対応が認められた。比抵抗減少量は異方性を示す が，焼なまし前後の集合組織に変化はなく，集合組織の影響 は少ない。

以上の諸結果から，冷間圧延板の焼なましによる降伏応力 異方性の変化には，冷間圧延によって形成された Deformation Zone やせん断帯などの高密度な転位セルを持つ領域の 配列異方性の影響が強いと考えられる。

おわりに, 比抵抗測定に協力して頂いた関西大学大学院生 阿部晴彦，天野英隆 両君に感謝する。

\section{参 考 文 献}

1) A. Hibino, T. Sakuma and T. Komatsubara: Mater. Sci. Forum 331-337, No. 2 (2000), 775.

2) 井上博史 : 軽金属, 42 (1992), 358.

3) N. Hansen and D. Juul Jensen: Acta Metall. Mater., 40 (1992), 3265.

4）小松伸也, 池田勝彦, 田畑義昭, (故) 合田剛久 : 軽金属, 44 (1994), 164

5) H. Inagaki and S. Kohara: Z. Metallkde, 88 (1997), 570.

6）小松伸也, 池田勝彦, 田畑義昭, (故) 合田剛久: 軽金属, 44 (1994), 439.

7）小松伸也, 池田勝彦，河本知広，田畑義昭，谷本孝弘：軽金 属, 48 (1998), 335.

8) E. Hashimoto and Y. Ueda: Mater. Trans. JIM, 35 (1994), 262.

9) K. Osamura and T. Ogura: Metall. Trans. A, 15A (1984), 835.

10) D. J. LIoyd, E. F. Butryn and M. Ryvola: Microstruct. Sci., 10 (1982), 373

11) R. Sandström: Z. Metallkde, 71 (1980), 681.

12) S. V. Harren, H. E. Dève and R. J. Asaro: Acta Metall., 36 (1988), 2435.

13）小松伸也, 池田勝彦, 生駒俊彦, 河野洋一：軽金属, 43 (1993) , 421 